UDK 783.3:784.12 Bach

\author{
David Greer \\ Durham
}

\section{BACH'S CANTATA NO. 140 AND THE TRADITION OF THE ALBA}

Lahko noč bi ti jaz vošil, Pa bo skoraj beli dan.

Oh adijo, ljubca moja, Jaz pa moram iti dam!

One of the most ancient and most universal of poetic themes is that of the alba. The oldest known example has been dated as far back as the 13th century B.C., and its continuing tradition has been traced in some fifty languages. ${ }^{2}$ The alba theme allows for many variations, but in its most common form it is this: two lovers spend the night together, and as the first signs of dawn impinge on them - such as the first rays of light entering their chamber, or the crowing of the cock, or the sound of the muezzin calling the faithful to prayer - they lament that their night of love must soon end and that they must part. The variety of treatment that this theme might receive is illustrated by the folksong from Bled placed at the head of this article, and by this one from Kranj:

Čuvaj vpije beli dan!

Al' si moj ljubi, še ne vstan'!

On vpije vsim zaspanim, aj zaspanim! ${ }^{3}$

To English readers the theme is best known not from a song or poem but from a play, Shakespeare's Romeo and Juliet. ${ }^{4}$

Juliet Wilt thou be gone? It is not yet near day;

It was the nightingale, and not the lark,

That pierc'd the fearful hollow of thine ear;

Nightly she sings on yond pomegranate tree.

Believe me, love, it was the nightingale.

\footnotetext{
1 'I would wish you goodinght, darling, but the white day will come soon. Oh farewell, my dearest sweetheart, for I must be going home!' Karel Štrekelj, Slovenske narodne pesmi, ii (Ljubljana, 1900-03), no. 1852

2 Arthur T. Hatto (ed.), Eos: an enquiry into the theme of lovers' meetings and partings at dawn in poetry (The Hague, 1965); see also Peter Donke, The Medieval Lyric (London, 1968).

3 'The watchman is calling the white day! Don't get up as yet, my love! He is calling all those sleeping, yes, those sleeping'. Štrekelj, op. cit., no. 2261.

4 Act 3 , scene $5,1-11$.
} 
Romeo It was the lark, the herald of the morn, No nightingale. Look, love, what envious streaks

Do lace the severing clouds in yonder east;

Night's candles are burnt out, and jocund day

Stands tiptoe on the misty mountain tops.

I must be gone, and live - or stay and die.

The fact that Romeo and Juliet are no longer illicit lovers, but secretly married, just serves to illustrate the adaptability of the genre.

At about the same time as Shakespeare was writing his last plays the following anonymous lyric was set to music by both Orlando Gibbons and John Dowland:

Ah, dear heart, why do you rise?

The light that shines comes from your eyes.

The day breaks not, it is my heart,

To think that you and I must part.

Stay, or else my joys will die

And perish in their infancy. ${ }^{5}$

Not surprisingly, John Donne put his own distinctive spin on the theme in a poem called Break of Day. In this poem Donne portrays the lover as a 'busied man' - or as we might say, 'business man' - stealing his moments of iove between appointments at the office:

'Tis true, 'tis day, what though it be?

O wilt thou therefore rise from me?

Why should we rise, because 'tis light?

Did we lie down because 'twas night?

Love, which in spite of darkness brought us hither,

Should in despite of light keep us together.

Must business thee from hence remove?

Oh, that's the worst disease of love:

The poor, the foul, the false, love can

Admit, but not the busied man.

He which hath business, and makes love, doth do

Such wrong as when a married man doth woo. ${ }^{6}$

In the religious verse of Richard Crashaw, another English poet of the early seventeenth century, the poet frequently draws on ideas and vocabulary from secular poetry. For example, in the alba the woman sometimes tries to persuade her lover that the light that floods the room comes not from the rising sun but from his own eyes. So

5 Orlando Gibbons, The First Set of Madrigals and Mottets (London, 1612), no. xv; John Dowland, A Pilgrimes Solace (London, 1612), no. ii (with a different first line, 'Sweet, stay awhile, why will you rise?'). See E.H. Fellowes (ed.), English Madrigal Verse 1588-1632, 3rd edition, revised by Frederick W. Sternfeld and David Greer (Oxford, 1967), pp. 113, 490. The lyric appears in numerous literary sources of the seventeenth century.

6 Helen Gardner (ed.), The Elegies and the Songs and Sonnets of John Donne (Oxford, 1965), 35. Second verse omitted. 
Crashaw, in The Holy Nativity of Our Lord God, adapts this fancy - including its rhyme of rise and eyes - and has the light come from the eyes of the infant Jesus:

It was thy day, sweet, and did rise

Not from the east, but from thine eyes. ${ }^{7}$

In another poem, The Glorious Epiphany of Our Lord God, Crashaw takes this idea a stage further, and imagines the sun as coming to see itself in the eyes of the holy child:

Look up, sweet babe, look up and see,

For love of thee,

Thus far from home,

The east is come

To seek herself in thy sweet eyes. ${ }^{8}$

Indeed, the more one studies the alba the more one realises that there is a constant interplay between the sacred and the secular. The religious significance of the light coming from the east, or the crowing of the cock at dawn, needs no elucidation here; but it is perhaps less known that dawn - from which day is born - was often used to symbolise the Virgin Mary, the mother of Jesus, who is the day. This equation was happily assisted by the fact the word alba means 'white', the colour of virginity. Moreover, as we survey the alba over the centuries, and in many different languages, we sometimes come across ideas derived from the Song of Songs. In fact, in some translations the Song of Songs itself was mistakenly given an alba setting. The English 'Authorised Version' of 1611 reads, 'My beloved is mine, and I am his: he feedeth among the lilies. Until the day break, and the shadows flee away, turn, my beloved, and be thou like a roe or a young hart upon the mountains of Bether'.

Many albas, especially those of the middle ages, feature a third character - the watchman. We have already had a glimpse of him in the song from Kranj. The watchman may be a friend of the lovers, keeping guard over them through the night to see that they are undisturbed; or he may be the sentry on the castle wall, or the watchman who patrols the streets and calls the hours. In Romeo and Juliet the role of the watchman is taken over by Juliet's nurse. Whatever his exact status, it is the watchman who warns the lovers of impending day. In Reis glorios by the twelfth-century Provencal poet Guiraut de Bornelh, the watching companion sings:

Reis glorios, verais lums e clartatz,

Deus poderos, Senher, si a vos platz,

Al meu companh siatz fizels ajuda;

Qu'eu non lo vi, pos la nochs fo venguda,

Et ades sera l'alba. ${ }^{10}$

7 L.C. Martin (ed.), The Poems English, Latin and Greek of Richard Crashaw (2nd edn., Oxford, 1957), p.248, lines 21-2.

8 Martin, op.cit., p. 254, lines 10-14.

9 ii.16-17; see Hatto, op.cit., p.87.

10 'King of glory, thou true light and brightness, mighty God, Lord, if it be thy will, grant constant aid to my companion; for I have not seen him since nightfall, and soon it will be dawn'. Hatto, pp. 359-60. 
At about the same time, the German poet Wolfram von Eschenbach gave these words to his watchman:

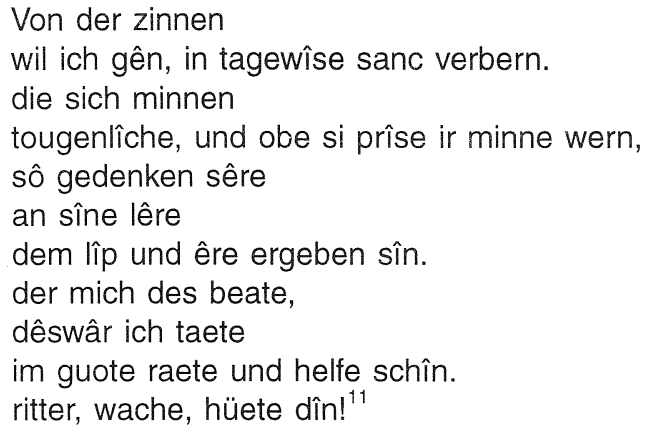

The voice of the watchman resonates through the Old Testament. In Isaiah lii.1 we read, 'Awake, awake; put on thy strength, O Zion; put on thy beautiful garments, $O$ Jerusalem'. And in Isaiah lii.8, 'Thy watchman shall lift up the voice; with the voice together shall they sing: for they shall see eye to eye, when the Lord shall bring again Zion'. The idea of the watchman passes naturally from the Old Testament to the New. Paul adopts the manner of the watchman when he tells the Corinthians, 'Awake to righteousness, and sin not', ${ }^{12}$ and the Ephesians, 'Awake thou that sleepest, and arise from the dead, and Christ shall give thee light'. ${ }^{13}$ And let us not forget the watchman's cry that goes up in Matthew xxv.6: 'Behold, the bridegroom cometh; go ye out to meet him'. It is easy to understand why the idea of the watchman should have remained such a potent one well into the later middle ages: we must remember that in the early centuries A.D. Christians lived in constant expectation of the return of Christ, and kept vigil for him at night. Indeed, it was out of such vigils that grew the night offices of monastic communities.

At the end of the sixteenth century the Lutheran pastor Philipp Nicolai (1556-1608) drew upon this rich fund of ideas, from St. Matthew to Eschenbach, when he wrote the words of the chorale Wachet auf, ruft uns die Stimme, first published in 1599. Under the sub-title 'Ein anders von der Stimm zu Mitternacht, und von den klugen Jungfrawen, die ihrem himmlischen Brautigam begegnen, Matth. 25', the first verse reads:

Wächet auf, ruft uns die Stimme

Der Wächter sehr hoch auf der Zinne,

Wach auf, du Stadt Jerusalem!

Mitternacht heisst diese Stunde;

Sie rufen uns mit hellem Munde:

Wo sied ihr klugen Jungfrauen?

Wohl auf, der Bräutgam kömmt,

Steht auf, die Lampen nehmt!

11 'I shall go down from the battlement without singing my song of dawning. If these secret lovers love their reputations they will heed the words of one who has their life and honour in his keeping. Were a man to ask it I would show myself ready with help and good counsel. Knight, wake up, be on your guard!' Hatto, pp. 453-54.

12 I Corinthians xv.34.

13 Ephesians v.14. 
Alleluja!
Macht euch bereit
Zu der Hochzeit,
Ihr musset inm entgegengehn! $!^{14}$

Scholars have shown how the melody used by Nicolai - as well as his words draws on ideas hallowed by tradition. Johannes Wolf was perhaps the first to point out that both the Stollen and the Abgesang incorporate a motif found in the Meistersinger repertory (Example 1). ${ }^{15}$ Others have shown how the opening phrase uses a formula

Example 1

Hans Sachs, Silberweise (transposed)

(a)

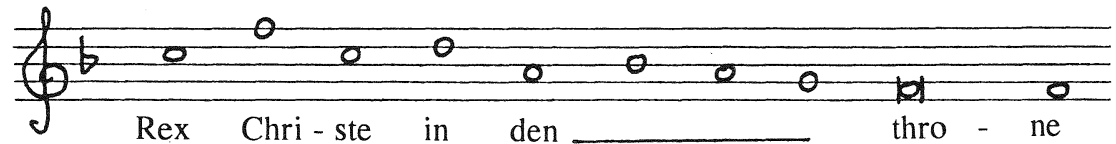

Wachet auf (Nicolai, 1599)

(b)

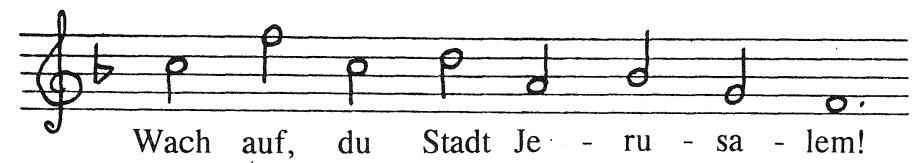

that can found in many melodies, such as the Gregorian Psalm Tone $\mathrm{V}$ and the fourteenth-century In dulci jubilo. Richard Wagner was to breathe new life into the old motif in his celebration of musical tradition, Die Meistersinger von Nürnberg (Example 2).

Example 2

Psalm Tone V

(a)

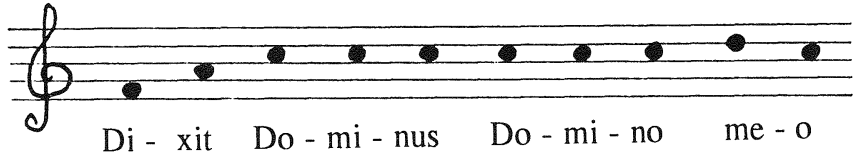

In dulci jubilo

(b)

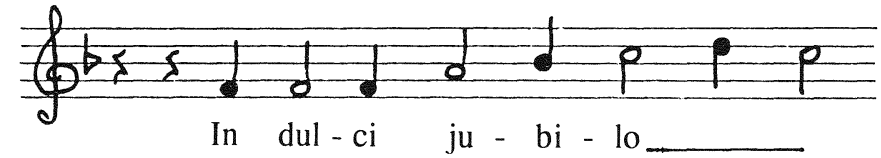

Wachet auf (Nicolai, 1599)

14 'Awake, the voice of the watchmen calls us from high on the tower; awake, you town Jerusalem', etc.

15 Johannes Wolf, Geschichte der Musik, i (Leipzig, 1930), 52; see also Walter Blankenburg, 'Die Kirchenliedweisen von Philip Nicolai', Musik und Kirche, xxvi (1956), 172-6. 
(c)

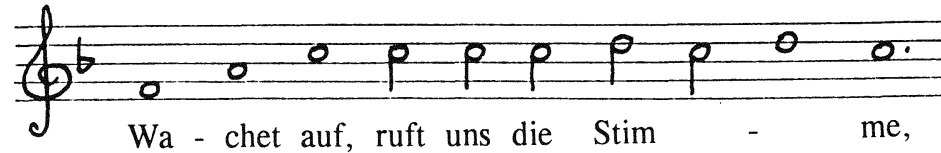

Wagner (transposed)

(d)

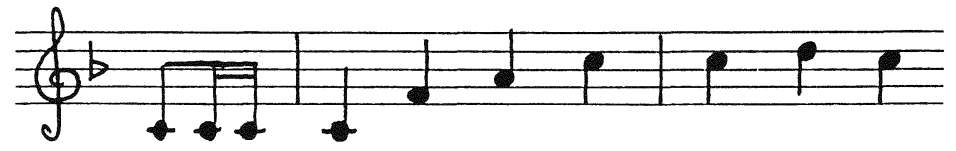

It was of course this chorale that J.S. Bach used as the basis for his Cantata No. 140 , composed (probably in 1731) for the 27 th Sunday after Trinity. ${ }^{16}$ The choice of chorale was a natural one, since the Gospel for that Sunday is Matthew 25.1-13, the parable of the Wise and Foolish Virgins, on which the text of the chorale is based. Much has been written about the chorale fantasia that forms the first movement. One feature, however, that has been less closely observed is the manner in which the instruments that Bach used in this movement were chosen to symbolise of the main topics of the text. The trio of oboes (two oboes and taille) - traditionally classified as 'haut' (loud) instruments, with strong outdoor associations - evokes the stately progress of the bridegroom across the desert. The chorale melody sung by the sopranos is doubled by a horn, symbolising the call of the watchman. At the same time, the violino piccolo approximates to the instrument variously known as a kit, poche, or Tanzmeistergeige, which, as the German name indicates, was used to accompany dancing, and which in the present context symbolises the festivities of the wedding feast. ${ }^{17}$ In this way the instrumentation provides a simultaneous commentary on the text.

It may be thought that, in focusing attention on the watchman, we have lost sight of the lovers, who after all are the principal characters in an alba. But not so. Although the point of departure for the Cantata is the story of the Wise and Foolish Virgins, the libretto (sometimes attributed to Picander) makes only passing reference to them. Instead, it concentrates on the Bridegroom (Christ) and Bride (the Christian Soul), and gives central place to them in the series of recitatives and duets which form the core of the work. In language that has proved problematic to more than one commentator, they pledge their love as fervently as any earthly lovers:

$\begin{array}{ll}\text { Soul: } & \text { Mein Freund is mein! } \\ \text { Jesus: } & \text { Und ich bie sein! } \\ \text { Both: } & \text { Die Liebe soll nichts scheiden! } \\ \text { Soul: } & \text { I will mit dir in Himmels Rosen wieden, } \\ \text { Jesus: } & \text { Du sollst mit mir in Himmels Rosen wieden, } \\ \text { Both: } & \text { Da Freude die Fülle, da Wonne wird sein! }\end{array}$

16 Gerhard Herz, Bach: Cantata no. 140 (Norton Critical Scores, New York, 1972), pp. 42, 51-2, 171. 17 Monteverdi, in Orfeo, uses the term 'violino piccolo' to mean a kit. 
Thus we see that in its featuring of watchmen and lovers at night, when the lamps are still lit, Bach's Cantata No. 140 acknowledges the tradition of the alba. There is no need for us to exaggerate this link; there may be, as Smend suggested, an element of Pietist influence in this emphasis on the relation between Jesus and the individual soul. ${ }^{18}$ The point is simply this: that just as Nicolai's melody draws on musical motifs from the past, so the text of the cantata picks up literary ideas that had long been current. And these play their part in contributing to the striking richness and resonance of the work.

\section{POVZETEK}

Ena najstarejših in najbolj univerzalnih poetskih tem je alba. Obstaja več različnih variant albe, vendar je njena najbolj običajna forma naslednja: ljubimca skupaj preživita noč in ko se pokažejo prvi znaki zarje - bodisi prvi žarki svetlobe, ki vstopajo v njuno sobo, bodisi petelinje petje ali glas muezina, ki kliče vernike $k$ molitvi - tožita, ker se bo njuna ljubezenska noč morala kmalu končati in se bosta morala posloviti. Alba na poseben način povezuje tudi posvetno in duhovno ustvarjanje. Pogosto zarja, iz katere se rodi dan, simbolizira devico Marijo, Jezusovo mater, ki je dan. Mnogo alb vključuje poleg ljubimcev še tretji element, nočnega stražarja, ki svari ljubimca pred grozečim dnevom. Njegov glas odmeva $v$ Stari zavezi ter se nato naravno prenese tudi $v$ Novo zavezo. Tudi nočni oficiji meniških redov so pravzaprav zrasli iz stalnega pričakovanja Kristusovega-ženinovega prihoda starokrščanskih skupnosti.

Iz teh idej je zrasel tudi koral Wachet auf, ruft uns die Stimme, ki ga je zložil luteranski pastor Philipp Nicolai in ga je za temelj svoje kantate št. 140 prevzel J.S. Bach. Bach se je razumljivo odločil za ta koral pri uglasbitvi kantate za 27. nedeljo po Sv. Trojici, ko se bere evangelij o pametnih in nespametnih devicah. Bach je $z$ ozirom na vodilno temo izbral instrumente $v$ prvem stavku: trio oboj spominja na veličasten pohod ženina skozi puščavo. Koralna melodija, ki jo pojejo soprani, podvojeni z rogom, simblozira klic nočnega čuvaja. Hkrati se violino piccolo približuje instrumentu, znanemu kot Tanzmeistergeige, ki v kontekstu predstavlja poročno slavje. Središčno pozornost libreto namenja ženinu (Kristusu) in nevesti (duša kristjana), ki si tako strastno kot zemeljski ljubimci obljubljata ljubezen. V orisu nočnega čuvaja ter nočnih ljubimcev se uvršča Bachova kantata št. 140 v tradicijo albe. 